\title{
Developing Flashcards and the Manual Book for Teaching English Vocabulary for Young Learners in Singaraja
}

Taharyanti, Gusti Ayu Putu Stella Mundi Early Learning Center taharyanti@gmail.com

\begin{abstract}
This was a Research and Development study which intended to develop flashcards and manual book as teaching media for teaching English vocabulary for young learner in Singaraja. The subjects of this study were five English teachers in Singaraja. They were SDN 1 Baktiseraga, SDN 1 Banjar Bali, SDN 2 Banyuasri, SDN 2 Pemaron, and SDN 3 Kampung Baru. This study used design model proposed by Hannafin and Peck (1988). The instruments used in this study were interview guide, questionnaires for teachers and students, and the evaluation sheet. The data gathered was analyzed qualitatively and quantitatively. The result showed that teachers actually did not have any representative flashcards. The flashcards developed in this study covered 11 topics of noun and they were provided by manual book to support the implementation of the develop flashcards. The quality of the flashcards and the manual book got score almost 5 (highest score) from experts, which categorized to the excellent category. From the aforementioned result, it can be concluded that the teachers did not have any representative flashcards, therefore the development of flashcards which contained 11 topics of noun was conducted, and was supported by manual book in which their qualities were excellent.
\end{abstract}

Keywords: The development of flashcards, flashcards for young learner

\section{Introduction}

Language consists of vocabulary, and it is a collection of words in the language which is known, learnt, and used by the speakers (Linse, 2005). Vocabulary was the basis component of the language which made the language became so useful for the communications. Hatch and Brown (1999) in Komachali and Khodareza (2012) state that a person's vocabulary is the set of words they are familiar with in a language. A vocabulary usually grows and evolves with age, and serves as a useful and fundamental tool for communication and acquiring knowledge. The vocabulary could not fall apart from the language itself. It was grows and evolves with age, which means the older you are the richer vocabulary that existed in your memory. From both theory by Linse (2005) and Hatch and Brown (1999), we could draw that the vocabulary teaching should be started from the early age. Because of the vocabulary was really important for the communication, and furthermore it was needed to help people from acquiring knowledge.

As Bastanfar \& Hashemi (2010) mentioned, "without grammar, very little can be conveyed, without vocabulary, nothing can be conveyed." It shows how vocabulary runs a main role of the existence of a language in a communication. People cannot talk event write anything without comprehending the vocabulary of the language. Vocabulary will be the important aspect and need to be taught since the very beginning level. It can be clearly seen how the learner need to learn vocabulary in the target language for comprehending the English language as well as their academic ability of the English subject. As young as vocabulary taught to the learner, as good as the result or the learner's ability would be in comprehending the target language.

Teaching English vocabulary is better to do from the very first level of the learner that is in the young learner level. "It is widely believed that starting the study of English as a Foreign Language (EFL) before the critical period, 12 or 13 years old will build more proficient speakers of English" (Shin, 2007). It was strengthen the opinion that young learner would be the best level for starting learn English. Young learners were classified into 
children of 7-12 years old, which can be found in the primary school or elementary school. They will not feel difficult to extent their learning to the other language skills such as, reading skill, listening skill, writing skill and speaking skill because they know the basis thing of the language, that is vocabulary.

In teaching vocabulary for young learners, there are so many references of media that can be used by the teacher in the classroom. The main point is the media have to be as interesting as possible, because the target learner is young learner. Young learners have a short span of concentration. Song, video, pictures, realia, miniature, authentic-like media, and card, are the examples of media that can be used in teaching vocabulary for young learner. In general, teachers are really familiar in using card or well known as flashcards in teaching vocabulary, in which containing words with its picture or its pronunciation. At some schools, teachers already had some items of flashcards made by themselves. They found flashcards was not really difficult to be made. By using flashcards, the teacher will be helped to teach vocabulary to the learners. Flashcards is a kind of media which does not need electricity in its implementation. The students can also experience it by touching and seeing the flashcards while learning the vocabulary. No wonder, Flashcards became a familiar media for vocabulary teaching.

In some schools, teachers already have some items of flashcards made by themselves. They found Flashcards is the easiest media to be made. By using flashcards, the teacher will be helped to teach vocabulary to the learners. Flashcards is a kind of media which does not need electricity in its implementation. The students also can experience it by touching and seeing the flashcards while learning the vocabulary. No wonder, Flashcards become a familiar media for the teacher in teaching vocabulary.

Based on the observation conducted in five Elementary Schools in Singaraja, only a few of the schools support the teaching and learning process with the teaching media. Two out form five schools have provided a good teaching media, such as flashcards and pictures. The rest two schools only have pictures as the teaching media, and one out from five schools did not provide any teaching media at all. The facilities provided at schools were still limited. Even though some of the Elementary schools have provided LCD projector, but the amount of the product is insignificant. The teachers cannot use it all the time they need. Moreover, the teacher did not prepare any non-printed media for teaching. There are some reasons stated why the teachers rarely never use any electronic media in teaching English at schools.

In using any non-printed media, the teachers have to plan and prepare it before at home. In facts the teachers said, they did not have time and enough skill to do so. In implementing the non-printed media at schools, such as using LCD projector, the teachers need more time to prepare it at the classroom. Meanwhile the time allotment for English subject is limited. The schools also did not have any language laboratory, which can help the teachers in conducting the teaching process using the non-printed media. Two out from five elementary schools have 70 minutes in a week for English subject. The rest of them only have 35 minutes in a week. It makes the teachers rarely never bring the LCD projectors to the classroom, because they would be run out of time in preparing the LCD and also teaching the material.

Because of the information in using the Flashcards in the classroom owned by the teachers were still limited, it led the researcher to find a solution by conducting this research. That was developing flashcards with more sophisticated design, durable, and also some activities in teaching vocabulary by using the flashcards by providing the manual book. The purposes of this study were to help the teacher at school to teach English vocabulary in an interesting way, to provide some references to the teacher in designing the activity in using flashcards as a media, and help the students to achieve the learning objectives easily. The study would be done by providing the flashcards and its manual book for teaching vocabulary 
for young learner. The product of this study was a collection of flashcards and the manual book that would be developed based on the students' and teachers' needs. The development of the flashcards will replace the ordinary flashcards with a new durable flashcards and could be used for some vocabulary categories. The manual book will complete the presence of the Flashcards as the innovative teaching activities for the teacher in teaching vocabulary using Flashcards.

\section{Methods}

In this study, researcher had considered to conduct this study among English teachers in Singaraja. As the respondent, the researcher has selected five English teachers who teach English in Elementary School. Those are SDN 2 Pemaron, SDN 2 Banyuasri, SDN 1 Baktiseraga, SDN 1 Banjar Bali, SDN 3 Kampung Baru. There is a principle reason why these schools are selected. The researcher needs to find a spread data among Singaraja. The object of the study was the development of Flashcard and its manual book for the guidance to use the Flashcard in the classroom. The Flashcard will contain pictures and words, especially noun. The Flashcard would be added by a new feature that was the frame card and the flipped screen, as an optional feature for teachers in using the flashcards.

In conducting the research, the researcher will conduct some activity using the instruments of the research. The following explanation will be about the method of the data collection.

1. As the first step, the researcher conducted an interview to five English teachers in Singaraja. The researcher was used an interview guide as the guidance and record the interview. The interview guide helped the interview run smoothly and efficiently, while the record helped the researcher to back up the result of the interview. During the interview, the researcher took some pictures of the media used at schools, especially for the pictures and flashcards used by the teachers at schools.

2. Secondly, the questionnaire was spread among five elementary schools in Singaraja. The questionnaires were intended for the teachers and the students. The questionnaire was about the media used by the teacher especially the use of Flashcard by the teacher and also the implementation of the flashcard in teaching and learning process. Through the questionnaire, the researcher will know the usage of the flashcard in the school and how it was implemented from both side, the teachers and the students.

3. Thirdly, the researcher designed the product based on the findings at school toward the English teachers. The researcher implemented researcher's diary to keep the data during designing the product.

4. Fourthly, the researcher conducted expert judgments to two expert lecturers. These two lecturers are the experts of education, especially who have expertise in TEYL. The data in the expert judgment will be collected by the evaluation form of the product. The evaluation of the product also came from the English teacher at school as the users of the product. The teacher gave their opinion and evaluation about the product.

In this study, the researcher would analyze the data through some techniques. The data collected in some phases will be analyzed differently based on the data itself. In the "need assess" phase, the data will be gained as the questionnaire result and the interview. It will be analyzed qualitatively. In the "design" phase, the data will be in a form of researcher's diary. It will be analyzed qualitatively. In the "develop/implement" stage, the data will be in a form of evaluation form by the expert judgments. The result of the evaluation sheet was 
analyzed quantitatively. The evaluation sheet used Likert Scale where score 5 is Excellent, 4 is Good, 3 is Average, 2 is Below Average, and 1 is Poor. Then the score was measured by following the formula below.

$$
\begin{array}{ll}
\mathrm{Mi} & =1 / 2(\text { Score Max }+ \text { Score Min }) \\
\mathrm{Sdi} & =1 / 3 \mathrm{Mi} \\
\mathrm{Sr} & =\frac{\text { Total Score }}{\text { Total Item }}
\end{array}
$$

Note:

Mi: Ideal Mean

Sdi: Ideal Standard Deviation

Sr $\quad$ : Score

Then, the data gathered was converted into some scales by using the formulas which was

\begin{tabular}{|c|c|}
\hline Score & Criteria \\
\hline $\mathrm{Sr} \geq \mathrm{M} i+1.5 \mathrm{Sd} i$ & Excellent \\
\hline $\mathrm{Mi} i+0.5 \mathrm{Sd} i \leq \mathrm{Sr}<\mathrm{M} i+1.5 \mathrm{Sd} i$ & Good \\
\hline $\mathrm{Mi}-0.5 \mathrm{Sd} i \leq \mathrm{Sr}<\mathrm{M} i+0.5 \mathrm{Sd} i$ & Average \\
\hline $\mathrm{M} i-1.5 \mathrm{Sd} i \leq \mathrm{Sr}<\mathrm{M} i-0.5 \mathrm{Sd} i$ & Below Average \\
\hline $\mathrm{Sr}<\overline{\mathrm{M}} i-1.5 \mathrm{Sd} i$ & Poor \\
\hline
\end{tabular}
adopted by Nurkancana and Sunartana (1992) as shown below.

Table 1. Formula Proposed By Nurkancana and Sunartana

Table 2. Criteria of Validity

\begin{tabular}{cc}
\hline Score & Criteria \\
\hline $\mathrm{Sr} \geq \mathbf{4 . 4 8 5}$ & Excellent \\
$\mathbf{3 . 4 9} \leq \mathrm{Sr}<\mathbf{4 . 4 8 5}$ & Good \\
$2.5 \leq \mathrm{Sr}<3.49$ & Average \\
$1.5 \leq \mathrm{Sr}<\mathbf{2 . 5}$ & Below Average \\
$\mathrm{Sr}<\mathbf{1 . 5}$ & Poor \\
\hline
\end{tabular}

\section{Findings}

\section{Findings and Discussions}

From the data collection, it can be described that not all teachers had flashcards to support their teaching and learning process in the classroom. There were 3 teachers had flashcards to support their teaching. Meanwhile, from further interview, for those who had flashcards, they stated that these flashcards were not enough because they still needed some flashcard's categories/topics. This was supported by the data where 2 teachers frequently used flashcards which contain all topics of material while the rest 3 teachers stated they did not use flashcards which covered all topics of material.

Somehow, the data gathered from the students responds, it was found that almost $100 \%$ teachers did not used media frequently in teaching. Secondly, it was found that the teacher did not use flashcards frequently to support their teaching in the classroom. The last, almost $100 \%$ students stated that their teachers did not use flashcards which covered all topics of material.

In doing the interview, the researcher asked 24 questions in accordance to dig deep information from the teachers. Researcher also took some pictures of the flashcards used by the teachers at school. The questionnaires conducted to the teachers and students. From the interview, the researcher found that (1) the availability of the teaching media at schools, 1 out from 5 English teacher said that the school did not provide any media for teaching the 
English subject, 2 out from 5 schools only provided pictures for teaching, the rest of the schools stated that they did not only have pictures, but also songs, ( 2 and 3 ) the form of the media, was it printed media or non-printed media. One of the schools did not have any printed or non-printed media, whereas 2 out from the 5 schools stated that they had nonprinted media in a form of songs and CDs of song only, the rest was only have pictures, (4) the condition of the media. 4 out from 5 schools which had teaching media said that the media was still good, even though some of them were old enough to be used, (5) the availability of flashcards at schools, most of the teachers said that they had flashcards at schools, (6) the frequency of using flashcards, one of the teachers never used flashcards at all, the rest of them said that they used flashcards when it was needed, that was in introducing the vocabulary only, (7) the authenticity of the pictures, one of the schools surely did not have any authentic pictures for the media, 2 out from 5 schools did not have flashcards in authentic pictures, whereas the rest 2 schools had some authentic pictures in their pictures collection, (8) the needed category of flashcards provided at schools, all schools said that the collection of flashcards or pictures that they had could not cover the material to be taught.

From the pictures of the kinds of flashcards, it found that the schools only had a flashcards with pictures only, there was no words of target language there. Only some of the flashcards contained the native language of the students in the back side of the flashcards. The size of the flashcards was also not too big, and some of them almost too small to be shown in front of the classroom. Only 2 out from 5 schools had authentic pictures for the flashcards.

From the teachers' questioner, the researcher found that 3 out from 5 teachers frequently used media in teaching. Meanwhile 2 out from 5 teachers rarely used media in teaching. It shows that $60 \%$ of teacher often used media in teaching. Besides, 3 out from 5 teachers frequently used flashcards in teaching, while 2 out form 5 teachers rarely used flashcards in teaching. The percentage shows $60 \%$ of teachers frequently used flashcards in teaching. For the second statement, it shows that 2 out from 5 teachers frequently used flashcards which could cover the material needed to be taught. Where 2 out from 5 teachers were never used flashcards which could cover the needed material to be taught. One of them stated that he rarely used flashcards which could cover the needed material to be taught in the classroom. In general, $60 \%$ of the teachers never or almost never used flashcards which could cover the needed material to be taught during the English teaching.

From the students' point of view, it was found a different opinion about the use of flashcards by the teachers. From the first question, 4 out from 5 schools said that their teacher never used media for teaching. It can be seen from the percentage in the table that was $0 \%$. Only one school, which also shows $6 \%$, a really small amount stated that the teacher frequently used media in teaching. For the second statement, 4 out from 5 schools show $0 \%$ for the use of flashcards in English teaching by their teacher. It means that their teacher never used the flashcards in teaching. Only one school shows $7 \%$ for showing how often their teacher used flashcards for English teaching, whereas the 7\% also show a small percentage for the use of flashcards in the classroom by their teacher. For the third statement, all of the five schools show $0 \%$ for the categories of the flashcards that the teachers had to cover the material needed. The data shows that the teacher did not have all of the categories/topics needed in English teaching.

In relation with developing the flashcards, especially the kinds of flashcards needed by young learners, topics of the content were identified. A syllabus analysis was conducted by analyzing the syllabus possessed by the elementary schools' teachers. From the analysis, it was found that there were 11 topics taught to the $4^{\text {th }}, 5^{\text {th }}$, and $6^{\text {th }}$ of elementary students. The next step conducted was analyzing the topics which could be taken into considerations in 
developing the flashcards. From the analysis, the topics chosen were 11 topics. They can be seen in the following table.

\begin{tabular}{cl} 
Table 3. The Chosen Topics for Developing the Flashcards \\
\hline No & \multicolumn{1}{c}{ Topics } \\
\hline $\mathbf{1}$ & Stationery \\
$\mathbf{2}$ & Things around the classroom \\
$\mathbf{3}$ & School's buildings \\
$\mathbf{4}$ & Public places \\
$\mathbf{5}$ & Animals \\
$\mathbf{6}$ & Fruits \\
$\mathbf{7}$ & Vegetables \\
$\mathbf{8}$ & Foods \\
$\mathbf{9}$ & Beverages \\
$\mathbf{1 0}$ & Electronic appliances \\
$\mathbf{1 1}$ & Transportations \\
\hline
\end{tabular}

After conducting syllabus analysis, the next step proceeded was developing flashcards. In developing the flashcards, a design of it should be drawn first. The designing process was conducted by using Adobe Photoshop Cs3 Intended. The design of flashcards base was divided into two sides, the front side and the back side. The front side was divided into two parts. The upper part was intended for the picture while the lower one was intended for the written word/s as well. The back side would present the students' native language.

The developed flashcards were also supported by the development of manual book which not only guided the teachers how to use them, but also how to implement them in various activities in English teaching. Specifically, the manual book covered overview of flashcards, how to use flashcards, how to implement the developed flashcards in some activities in English teaching. The activities contained in the manual book were 20 activities which can be seen in the following table.

In developing the flashcards, the manual book with some activities were also developed. The manual book was developed using the standard Bahasa Indonesia. Bahasa Indonesia was chosen since 1 out from 5 teachers was not graduated from an English department. The researcher hope that all of the English teacher in Singaraja could use this product, so Bahasa Indonesia was the best solution to be used in the manual book. Moreover, the other Elmentary school teachers could use it because in general the teacher in elementary school mostly graduated from Education of Primary School teacher (Pendidikan Guru Sekolah Dasar). Which means that they did not really focus on English only. So the use of standard Bahasa Indonesia in the manual book would help many elements of educators in Singaraja.

The score for the quality of the product from the experts and the teachers' evaluation were almost excellent for both the flashcards and the manual book. There was suggestion proposed by the experts that were changing the background color of animal's category from dark blue into the brighter color to make it more readable. The suggestion was then developed into in the revision steps.

\section{Discussions}

Vocabulary mastery has become the focus of every primary education instructions in Indonesia. Some teachers have put verbal and non-verbal forms into vocabulary learning where students do some activities in written and/or in verbal forms. These forms are commonly implemented through the implementation of media such as realia and flashcards since those media are the common media for Indonesian teachers (Kusuma, Adnyani \& Taharyanti, 2017). 
As one of the common media used by teachers, the flashcards implemented at schools in this study could not be categorized as flashcards at all, because of the shape of the flashcards and the contained material in the flashcards. Even though that the teachers said that they have flashcards, but the flashcards were not suitable with the criteria of flashcards. Moreover, the students argued from the questionnaire that their teacher rarely used the flashcards and most of them stated that the teacher never used flashcards at all. The problem of the flashcards at schools also added by the categories of flashcards provided cannot covered the material needed based on the syllabus.

According to Komachali \& Khodareza (2012) flashcards are cards which contain words, sentences, or pictures. The contained words or sentences should be placed at front or behind the cards. From this definition, it can be concluded that flashcards are not only pictures but also contain words or sentences describing the pictures. Therefore, it could be the reasons that the students stated their teachers did not have any flashcards then.

From the aforementioned phenomenon, it can be concluded that the teachers need the real flashcards to support them in teaching and contain topics of material taught in elementary schools. Therefore, this study was conducted to develop flashcards. Meanwhile, in developing the flashcards, as explained previously, a syllabus analysis had been conducted to know the topics taught and to know the possibility of developing the topics of the present flashcards.

Because of the limitation of time and budget, the researcher only develop the product until the steps where the revision conducted after the evaluation from the expert and 5 English teachers. From the preliminary study on the development of flashcards, it found that this study were different. It was diferent in some topics, those are the kinds of the flashcards and the pitures contained in the flashcards. Inayah (2010) developed the flashcards into words flashcards only, while the researcher developed the flashcards with words and pictures. Besides, Mojarradi (2014) developed the flashcards using an animation picture which not relevant with the theory proposed by Sadirman (2006) that picture should presented in its real condition or authentic. Besides this flashcards were developed with the authentic pictures, the flashcards also developed with the manual book. It makes the developed flashcards became different with the previous study in developing flashcards.

\section{Conclusion}

This study was designed by using Hannafin and Peck Design Model. There were three phases (need assess, design and develop/implement) conducted during the development of the product and the last was the evaluation from the experts and revision. From the steps conducted during the study, it can be concluded:

1. There were 11 categories or topics could be developed into flashcards. Form the syllabus analysis which combined with the schools' yearly program and semester program, there are 28 topics or categories for elementary schools students, grade $4^{\text {th }}$, $5^{\text {th }}$, and $6^{\text {th }}$. Based on the observation, some of the topics were not considered as noun, since the develop flashcards only developing the nouns, because noun was dominating the topic teaches for young learners. The words or vocabularies chosen were based on the students cultural background, or contextual.

2. The flashcards were designed by using Adobe Photoshop Cs 3 Intended and contained authentic pictures and written words. The flashcards were also supported by manual book which was about how to use them and contained 20 activities in its implementation in English teaching. The manual book was designed and developed using Microsoft Word 2007, for the cover of the manual book, it was developed using Adobe Photoshop Cs 3 Intended. 
3. The quality of the flashcards was shown by the data gathered from 6 experts who varied from expert in media and 5 teachers of elementary schools. The results showed that the product of either the flashcards and the manual book were excellent.

\section{References}

Bastanfar, Ali \& Hashemi, Toktam. (2010). Vocabulary Learning Strategies and ELT Materials A Study of the Extent to Which VLS Research Informs Local Coursebooks in Iran. International Education Studies Journal. Vol. 3 (3), p. 158-166

Howard, Jocelyn and Major, Jae. (2005). Guidelines for Designing Effective English Language Teaching Materials. Proceedings of the 9th Conference of Pan-Pacific Association of Applied Linguistics. pp. 101-109.

Inayah, Siti. (2010). Using Flashcard to Improve Students' Understanding on Present Continuous Tense (An Classroom Action Research at the 7th Grade of MTs YAMIDA Grobogan in the Academic Year of 2009/2010). Unpublised Thesis. Semarang: Walisongo State Institute for Islamic Studies

Komachali, \& Khodareza, M. E. (2012). The Effect of Using Vocabulary Flash Card on Iranian Pre-University Students' Vocabulary Knowledge. International Education Studies, Vol 5(3), p. 134-147.

Kusuma, I.P.I, Adnyani, N.L.D.S, \& Taharyanti, G.A.P. (2017). Developing 10 Interesting Games as Alternatives to the Monotonous Use of Flashcards for Vocabulary Learning and Assessments. Script Journal: Journal of Linguistic and English Teaching. Vol 2 (1). p. 68-82.

Linse, Caroline T. (2006). Practical English Language Teaching: Young Learners. Singapore: McGraw Hill Companies, Inc.

Mojarradi, Saeed. (2014). The Effect of Using Flashcards on ESL (English as a Second Language) Students' Ability to Learn Vocabulary. International Journal of Scientific World. Vol.2 (2), p. 56-61

Nunan, David. (2003). Practical English Language Teaching. First Edition. Singapore: Mc Graw-Hill Company.

Sadiman, Arief S et. al. (2006). Media Pendidikan Pengertian, Pengembangan dan Pemanfaatannya. Jakarta: PT Raja Grafindo Persada.

Shin, Joan Kang. (2006). Ten Helpful Ideas for Teaching English to Young Learners. Teaching Young Learners Journal. Vol. 44(2), p. 1-7

Tolbert, Joshua B, et. al. (2015). Guided Visual Vocabulary Practice: Spanish Language Vocabulary Instruction for Students with Learning Disabilities and Possibilities beyond the Foreign Language Classroom. Journal of language Teaching and Research. Vol.6 (2), p. 241-249

Tomlinson, Brian. (1998). Materials development in Language Teaching. U. K: Cambridge University Press. 